\title{
The Physician's Right to Due Process In Public and Private Hospitals: Is There a Difference?
}

\author{
by Arthur F. Southwick, J.D., M.B.A.
}

\begin{tabular}{|c|c|c|}
\hline $\begin{array}{l}\text { This article will discuss the } \\
\text { licensed physician to acquire } \\
\text { ain a hospital medical staff app } \\
\text { nent. The focus of the discuss } \\
\text { the relationship between the } \\
\text { endent fee-for-service private } \\
\text { itioner and the community gen }\end{array}$ & $\begin{array}{l}\text { staff. Failure to do so can r } \\
\text { liability. } \\
\text { The hospital's duty to e } \\
\text { sonable care in the selectio } \\
\text { tion of independent medica } \\
\text { ers is separate and distinct } \\
\text { hospital's vicarious liability } \\
\text { injuries resulting from maln }\end{array}$ & $\begin{array}{l}\text { y. } \\
\text { y to use reasonable } \\
\text { ff privileges to } \\
\text { be delegated to the } \\
\text { staff, to the local } \\
\text { to any other group } \\
\text { hospital's board of } \\
\text { odicate its legal }\end{array}$ \\
\hline $\begin{array}{l}\text { this } \\
v- \\
\text { ed as } \\
\text { ly it } \\
\text { table } \\
o \text { as a } \\
\text { this } \\
s \text {, if } \\
\text { vis- } \\
\text { I is }\end{array}$ & $\begin{array}{l}\text { ss of the } \\
\text { oth the } \\
\text { he em- } \\
\text { he vio- } \\
\text { st of the } \\
\text { yer is li- } \\
\text { ght, in } \\
\text { id } \\
\text { rk. }{ }^{2} \\
\text { d in } \\
\text { deat }\end{array}$ & $\begin{array}{l}\text { govern- } \\
\text { le care } \\
\text { edical } \\
\text { ic- } \\
\text { intments } \\
\text { to sub- } \\
\text { cess. It } \\
\text { duty of } \\
\text { g dect- } \\
\text { itments } \\
\text { eges } \\
\text { e }\end{array}$ \\
\hline
\end{tabular}

Excluded from this analysis are situations where the doctor is an employee of a hospital or health care institution. Also excluded are cases involving hospitals which limit their service to particular patients $(e, g$., the mentally ill or children), and university-owned teaching hospitals that impose a faculty appointment in the medical school as a pre-requisite to staff privileges.

In order to understand the basis for the hospital's concern in appointing or re-appointing physicians to its medical staff, it is important to realize that the hospital, as a legal entity, bears the ultimate responsibility for the standards of clinical practice exercised by its entire professional staff. The hospital's governing board (typically referred to as the board of trustees) has a duty to the institution's patients to exercise reasonable care in the appointment and retention of the independent, fee-forservice physicians on their medical

Mr. Southwick is Professor of Business Law, Graduate School of Business Administration, and Professor of Hospital Administration, School of Public Health at The University of Michigan, Ann Arbor. simply, public policy. It facilitates collection of compensatory damages from a presumably financially responsible party (the employer) while encouraging the employer to supervise and regulate more closely the activities of its employees.

In contrast to vicarious liability is the hospital's direct duty to the patient to use due care in the appointment of independent physicians to its medical staff. When patients sue for a breach of this duty, it is not necessary to allege and prove that an employment relationship exists between the hospital and the physician, nor is it necessary to prove that the doctor's negligence was within the scope of his or her employment. Rather, the patient need only allege and establish that the hospital was negligent in appointing or re-appointing the doctor to the medical staff or granting him or her privileges, and that this negligence was the proximate cause of injury or damage to the patient. If the hospital knew or ought to have known that the physician appointed to its staff was incompetent, then liability will attach. Breach of this duty is sometimes referred to as corporate negligence or

duties regarding management of the institution, whether in business or clinical affairs. It has been suggested that the governing body, which may be composed primarily or even entirely of lay persons, is incapable of making judgments with respect to matters of professional competence, and, accordingly, that decisions regarding appointment of medical staff and delineation of privileges for individual physicians should be made by physicians. Law-making bodies, whether the courts or the legislatures, have decided emphatically to the contrary on the policy that responsibility must be vested in the governing board. 4 The board, however, may delegate to the medical staff the authority to make recommendations with respect to staff appointments and clinical privileges, but the role of the medical staff is limited to such advice and recommendation. The board must retain responsibility for such decisions. ${ }^{s}$

In the exercise of this duty, however, the rights and procedures accorded applicants for staff appointments or clinical privileges must adhere 
to substantive and procedural due process. It is the view of this author that the duty of the governing board in rendering decisions with respect to staff appointments and in delineating clinical privileges is the same for public and private hospitals. ${ }^{6}$

Requirement for Due Process

Over 50 years ago, the United States Supreme Court held that a licensed physician does not have a constitutional right to a medical staff appointment, even when the hospital involved is public. ${ }^{7}$ However, when the hospital in question is a public or governmental hospital, the Fourteenth Amendment to the U.S. Constitution comes into play. The Fourteenth Amendment provides that ". . . no state [shall] deprive any person of life, liberty, or property, without due process of law; nor deny to any person... . the equal protection of the laws lemphasis supplied]." It must, however, be stressed that the Fourteenth Amendment is not applicable in the absence of state or governmental action. Private parties, including hospitals, are constitutionally required to extend due process or equal protection only when they are so closely involved with governmental interests as to be considered engaged in "state action."

Where "state action" can be established, a hospital must extend both substantive and procedural due process as well as equal protection to a physician who makes an initial application for appointment to the medical staff and to a current member of the staff subject to disciplinary action. ${ }^{9}$ Substantive due process creates and defines rights and duties relative to the legal relationship between the hospital and the physician. The issue arises when property or other rights are directly affected by "state action." Substantive due process and equal protection require the hospital to act reasonably, non-capriciously, nonarbitrarily, and consistent with a permissible objective. Procedural due process relates to the method and means by which substantive rules are made and administered. It requires a hospital to utilize a fair procedure when implementing and enforcing its rules and regulations. More will be said about substantive reasonableness and procedural faimess later in this article.

What can constitute "state action?" The Fourth Circuit Court of Appeals has expressed the view that the receipt by the hospital of substantial amounts of federal funds entitled physicians seeking medical staff appointments to equal protection of the law. ${ }^{10}$ On the other band, the Second Circuit has affirmed a lower federal court ruling that held that a private hospital, which revoked a physician's privileges upon his plea of guilty in a criminal assault proceeding, was not engaged in "state action." According to the Second Circuit, state action sufficient to entitle the doctor to constitutional protection is present only in the extremely linited situation where (a) government involvement with the private hospital is significant, (b) state activity causes the alleged injury to the doctor, and (c) the state aids, encourages, or connotes approval of the activity. ${ }^{12}$ In applying this three-pronged standard, the Second Circuit held that government does not aid or approve the activity nor cause the injury simply by providing funding to the hospital or by its regulation of the institution through licensure, certificate of need legislation, or other controls..$^{13}$ The court further stated that a private hospital is not performing a public function when it appoints physicians to its medical staff. ${ }^{14}$

Several sources of law are imposing requirements of reasonableness apon the private hospital that are essentially equivalent to the constitutional standards applicable to public hospitals or those private hospitals deemed involved in state action.

Other Sources of Due Process Protection

Constitutionally, public hospitals must grant due process and equal protection to physicians applying for an appointment to the medical staff and to current members of the staff being subjected to disciplinary proceedings.

Most courts that have addressed this issue, however, have held that private, non-profit hospitals need not accord physicians these rights. Thus, the due process rights of physicians vis-a-vis a hospital do differ depending upon the public or private ownership of the institution. Many commentators have suggested that this dichotomy is neither just nor equitable, since both public and private hospitals serve the same community. Additionally, several sources of law are imposing requirements of reasonableness upon the private hospital that are essentially equivalent to the constitutional stanciards applicable to public hospitals or those private hospitals deemed involved in state action. These include: (a) the federal Conditions of Participation; Hospitals that apply to hospitals participating in the Medicare program, is (b) the Standards of the Joint Commission on the Accreditation of Hospitals, ${ }^{16}$ and (c) a number of state court decisions. ${ }^{17}$

Each of these legally binding standards requires a private hospital to act reasonably and to accord procedural fairness when appointing and disciplining its medical staff. The Conditions of Participation in the Medicare program establish the criteria for the selection of medical staff as individual character, competence, training, experience, and judgment. These criteria are contained in federal regulations that have the force of law. 1s Similarly, the Standards of the Joint Commission on Accreditation of Hospitals require that the appointment or re-appointment of physicians, the "specific delineation of clinical privileges, and the periodic indepth reappraisal of each staff member," be conducted on the basis of the "individual's training and/or experience, current competence, professional ethics, and, if requested, health status." 19

Similarly, several state court decisions have held that a private, nonprofit hospital must grant physicians the essence of substantive and procedural due process on the basis of public policy and the common law, notwithstanding the lack of a constitutional mandate. This trend was inaugurated in 1963 when the New Jersey Supreme Court held that a private hospital could not arbitrarily refuse to consider the application of an osteopathic physician, especially where it was the only medical institution in the community. ${ }^{20}$ The court reasoned that the hospital was vested with a public interest and possessed a fiduciary relationship to patients and to members of the medical community. In short, the court held that a private, non-profit hospital is not truly "private" in the classical sense of being allowed to deal with licensed physicians on whatever basis or criteria it wishes. Rather, as an institution open to and serving the public, it must act reasonably and non-arbitrarily in appointing and retaining medical staff and must utilize a fair procedure for evaluating a physician's credentials.

The New Jersey case has, in essence, been adopted and followed by courts in a number of jurisdictions. ${ }^{21}$ The result is that the range of the hospital's discretion in appointing physicians 
to its medical staff has been narrowed, while the rights of physicians have been expanded by a standard of reasonableness and a recognition that physicians are entitled to a fair evaluation of their credentials and competence.

It should be noted that in other contexts the law has equated the duties of public and private health care institutions. For example, public and private hospitals that maintain an emergency room may not refuse to see a patient who comes to the facility seeking emergency care relying upon the hospital's representation that it is equipped and staffed to provide such care. ${ }^{22}$ Similarly, all hospitals that have received federal financial assistance directly or supplemental to the HillBurton Act must provide a certain volume of free care to patients unable to pay. ${ }^{23}$ Various sources of law (constitutional, statutory, and administrative regulation) at both the state and federal level of government prohibit hospitals and other institutions serving the public from discriminating with respect to accommodations, services, or privileges on the basis of race, color, creed, national origin, and, in some circumstances, sex. ${ }^{24}$ Lastly, many states have rejected the application of the doctrine of sovereign immunity which resulted in public hospitals being immune from tort liability, just as courts earlier overturned the doctrine of charitable immunity which resulted in private, non-profit hospitals no longer being immune from tort liability. The Michigan Supreme Court, for example, held in 1960, that it would impose tort liability on a charitable hospital, ${ }^{25}$ and in 1978, rejected governmental immunity for a public hospital even though such immunity was granted by statute to any governmental agency performing a "governmental function." For the purpose of tort liability to its patients, the Michigan court held that the ownership and operation of a hospital was not in the category of a "governmental function" sufficient to support a difference between private and public hospitals. ${ }^{26}$

Accordingly, both as a matter of developing law and sound managerial policy, all hospitals, public or private, should implement policies observing the essence of both substantive and procedural due process. All hospitals should serve their respective patient and physician communities in accordance with uniform, reasonable, and non-ciscriminatory standards regardless of whether they are public or pri- vate. Fairness and logic, as well as the trend in the law, would seem to suggest that all hospitals should be held to the same standards when appointing physicians to their medical staffs or when delineating clinical privileges.

\section{Professional Standards} and Institutional Objectives

Those who resist the view that licensed physicians are entitled to due process and equal protection need not fear that the hospital will be without adequate means to control and monitor the competence of its staff. Courts have generally upheld as reasonable and non-arbitrary any rule or standard bearing a rational relationship to professional standards of patient care, the objectives of the hospital, or the character and ethical behavior of the individual physician. As regards professional standards, courts have sustained hospital by-laws requiring specific documentation of credentials upon application to the hospital, ${ }^{27}$ delineation of clinical specialty privileges, ${ }^{28}$ the monitoring and controlling of staff practice, ${ }^{29}$ and summary suspension from the staff if patient care is threatened and provided such action is followed by a timely hearing. ${ }^{30}$

Similarly, rules that rationally relate to the objectives of the institution will be upheld as reasonable. For example, hospitals may require all staff physicians to carry adequate malpractice insurance in order to maintain the fiscal integrity of the hospital. ${ }^{31}$ Similarly, a hospital can deny appointment on the basis that bed space in a certain department or on a particular service is limited, or on the ground that a sufficient number of certain specialists are currently on the staff. ${ }^{32}$ To illustrate, a New Jersey court held that a hospital could deny staff appointments to two qualified surgeons upon evidence that surgical coverage at the hospital was already adequate, that additional surgeons would likely increase the number of surgeries performed, and that the needs of the patient community would not be served by additional surgeries. ${ }^{33}$ Such decisions by the governing body must, of course, be documented by credible evidence. A blanket moratorium on all staff appointments, especially if enforced inconsistently, will be found to be arbitrary and unreasonable. ${ }^{34}$

Courts have generally sustained exclusive service contracts entered into by both public and private hospitals so long as they are reasonable and non- arbitrary, and even though they tend to restrict appointments to a medical staff. In such arrangements, the hospital contracts with a group of physicians for the provision of specialized professional services, thereby closing the service to all other physicians regardless of their qualifications and competence. Older cases had no hesitation in approving exclusive contracts for radiology and pathology, ${ }^{33}$ and more recent cases have upheld such agreements for cardiac catheterization, nuclear medicine, and renal hemodialysis. ${ }^{36}$ In each case, the hospital was able to show valid reasons, e.g., enhancement of patient care standards, improvement of teaching programs, or administrative efficiency, for its decision to enter into an exclusive contract.

Not all hospital by-law provisions are, however, upheld and certain rules have been struck down as being unreasonable, arbitrary, and without any rational relationship to either standards of patient care or institutional objectives. For example, requirements that all persons appointed to the medical staff be members of the county medical society or some other named professional group have been rejected, ${ }^{37}$ as have been vague and ambiguous rules stating that clinical privileges could be reduced "in the best interests of the hospital and its patients." 38 Similarly, a requirement that the doctor's office be located in the same county as the hospital was rejected. ${ }^{39}$ A rule that required each applicant to the staff to supply two references from current members of the staff, 40 and a requirement of a governmental hospital in rural Tennessee (where there were only six physicians practicing in the entire county) that persons granted major surgical privileges be certified by the American Board of Surgery or be eligible for certification, ${ }^{41}$ were held as unreasonably related to institutional objectives.

By-law provisions that provide for the exclusion of an entire class of persons authorized by local law to perform limited health care functions, for example, podiatrists or physician's assistants, may also be rejected as unreasonable and contrary to public policy. ${ }^{42}$ If local law grants such individuals rights of limited practice, then it follows that hospitals that are required to act reasonably and non-arbitrarily vis-a-vis the medical or osteopathic physician, should also be required to act reasonably with respect to the limited practitioner. ${ }^{43}$ It is not required that full clinical privileges be granted 
to a practitioner of the healing arts. Rather, hospitals should be required to evaluate fairly, objectively, and based upon reasonable criteria applications for privileges by legally recognized practitioners. ${ }^{44}$ This requires evaluation of the individual's training, experience and competence in relationship to standards of patient care and institutional objectives.

One of the more perplexing current issues is the extent to which a hospital can go in denying a staff appointment or in disciplining a member of its staff for personal behavior considered contrary to generally accepted ethical, social, and moral mores. One thing is certain: hospital counsel must have a precise set of facts in order to succeed in a move to deny or withdraw staff privileges. However, a physician's wrongful conduct in the past may not per se be a proper basis for denying a current application for appointment. The applying physician carries the burden of providing evidence of his or her reformation and rehabilitation, and when his or her references fail to provide this evidence, the hospital may deny the appointment. ${ }^{45}$ Moreover, the "good character, qualifications, and standing" of the applicant physician are legitimate and justifiable areas of inquiry provided that they are applied fairly and that there is evidence at the hearing that the physician lacked either physical or social fitness. 46 "Intolerable personal behavior" consisting of frequent use of unacceptable language and rude behavior in the presence of patients and visitors has been held sufficient to dismiss a physician from the staff. ${ }^{47}$ Likewise, a physician's failure to document his "adherence to the ethics of [his] profession, [his] good reputation and [his] ability to work with others," as required by the hospital's medical staff by-laws, was found to be a proper basis for rejecting his application for appointment to the staff. 48

A recent California case, however has held that a requirement that applicants for staff privileges be able to work with others must be reasonably related to standards of patient care. If an applicant is rejected, the hospital must be prepared to show that his or her inability to "work with others" presented a "real and substantial danger that patients ... might receive other than high quality medical care." 49 Vague and ambiguous by-law provisions that are susceptible to arbitrary or discriminatory implementa- tion, such as a provision requiring applicants to be "temperamentally and psychologically suited for cooperative staff-functions," have also been rejected by the courts. ${ }^{50}$

\section{Procedural Due Process}

It is often more important to accord physicians procedural due process than it is to be unduly concerned about whether or not a given standard or criterion is "reasonable and nonarbitrary" as a matter of substance. This is because, practically, the denial of procedural faimess is more likely to generate hostility and actual litigation by an aggrieved physician. Physicians can better understand a substantive rule they do not agree with than they can accept procedural arbitrariness concerning their application for staff privileges. Also, it is easier for the physician's attorney to attack the procedure by which his or her client was denied a medical staff appointment or subjected to discipline than it is to attack the merits of the rule or requirement. Thus, as a matter of "preventive law," it is advisable for private hospitals to grant the essence of procedural due process to current members of the staff as well as to new applicants, whether or not the law of the particular jurisdiction actually mandates due process. Moreover, hospitals accredited by the Joint Commission are required to adhere to procedural due process. ${ }^{51}$

What is procedural due process? Simply, but accurately, stated as a matter of constitutional law, it is fundamental fairness under all the facts and circumstances. The specific elements of a fair procedural evaluation of a physician's qualifications and competence may thus differ depending upon time, place, and circumstance.

The minimal requirements of procedural due process have been articulated as follows: The physician is entithed to: (l) written notice of reasons for denial of appointment or of the charges against him or her; (2) an opportunity for a timely hearing after such notice; (3) a relatively impartial hearing body; (4) an opportunity to produce evidence and witnesses on his or her behalf and to refute the hospital's proferred evidence; ( $\$$ ) a finding by the hearing body based upon substantial, credible factual evidence; (6) written notice of the hearing body's recommended decision together with the reasons for the decision; and (7) an opportunity to appeal the decision. ${ }^{52}$

In the situation where en institution is attempting to take away or diminish a physician's privileges, the notice of charges against the doctor must be sufficiently specific to allow him or her to answer. Additionally, in order that the

It is often more important to accord physicians procedural due process ... the denial of procedural fairness is more likely to generate hostility and actual litigation by an aggrieved physician.

doctor may adequately prepare his or her response, he or she is entitled to know in advance of the hearing the particulars of the evidence against him or her, including, for example, incident reports, references to specific cases or alleged deficiencies, and peer review records. ${ }^{53}$ Medical and administrative staff are well advised to collect and prepare this information with care and to treat it discretely in order to expedite the proceedings against the allegedly errant physician and to minimize the possibility of a lawsuit.

\section{Hearing Requirements}

The hearing panel can consist exclusively of physicians or it can be composed of both physicians and lay persons. It must be composed of impartial persons. This does not mean, however, that the members need be entirely divorced from and devoid of prior knowledge of the case; rather, the test of constitutional impartiality is "good faith objectivity." Thus, persons asked to render a decision are not disqualified simply for the reason that they had prior knowledge of the situation or because they participated in the original investigation that led to the charges..$^{54}$ The premise is that responsible and honest persons within the hospital can make fundamentally fair decisions.

Likewise, the hearing need not conform with the formality and technicality of a courtroom proceeding. Hearing panels do not have the power of subpoena and they cannot compel the attendance of witnesses..$^{55}$ Therefore, there is no legal right to confront and to cross-examine witnesses unless they testify voluntarily. Cross-examination of those who supply adverse information is not an essential ingredient of due process. ${ }^{56}$ However, as noted earlier, the doctor must be permitted to present his or her own witnesses and to refute adverse evidence. The burden of proof at the hearing may be placed upon the physician, but the decision must be based ubon and documented by sub- 
stantial, credible evidence. ${ }^{97}$ Further, the decision must be based solely on evidence produced at the hearing, not on knowledge acquired elsewhere.

Several cases have held that the physician is not entitled as a matter of law to representation by legal counsel at the hearing. New Jersey, however, has held to the contrary, subject to reasonable rules specified by the hospital. ${ }^{58}$ Whether or not to have counsel is the physician's choice: The attorney will be allowed to marshall evidence, explain adverse material, and present argument. In jurisdictions not following New Jersey's rule, the physician should be allowed counsel at the hearing if the hospital's lawyer is present.

The notice of denial of a physician's application for privileges, which must be followed by an opportunity for a hearing, must be timely. Undue or extended "deferral" of an application is violative of due process. In short, a refusal to decide or to provide reasons for the decision, deprives the doctor of a fair hearing. The concept of "fundamental fairness under all circumstances" is the guiding rule. Thus, in one case where the by-laws provided that a hearing would be held within ten days of a request by the doctor (who had been notified of his suspension from the staff) there was no violation of procedural due process when the hearing was convened 15 days after his request. ${ }^{59}$ The 5 -day delay was insignificant since the doctor was not damaged or prejudiced by the minor, technical violation of the by-laws.

Generally, the doctor has a right to appeal a recommendation of a hearing committee to the hospital's board of trustees. The appeal to the board can be and should be restricted to reviewing whether by-law provisions were followed and whether there was substantial evidence to support the decision. As mentioned earlier, the final decision is the responsibility of the board.

When is a hearing and review procedure required? As assumed throughout this discussion, the physician is entitled to due process when his or her initial application for appointment is denied or when an existing appointment is not renewed, suspended, or revoked. The Joint Commission requires such procedures when clinical privileges are subject to "curtailment," as well as in cases of suspension or revocation. ${ }^{60}$ The meaning and definition of "curtailment," however, is not clear. As a matter of practicality, and in the interest of maintaining standards of clinical practice, the following should not be considered curtailments of a physician's privileges: medical staff programs to monitor an individual's professional performance; a letter of reprimand or admonition directed to a physician; a requirement for consultation; or a requirement that a physician seek additional training or education. In short, peer review and quality care monitoring can be implemented without conducting hearings. ${ }^{61}$ To argue otherwise would be inconsistent with the hospital's duty to monitor the quality of professional practice. In order to avoid problems, this dividing line between peer review of a physician's practice and curtailment, suspension, or revocation of privileges should be concisely explained in the medical staff by-laws.

When a physician has a grievance, he or she must invoke the hearing and appeal procedure provided by the hospital before going to court. As a general principle of administrative law, administrative remedies must be exhausted prior to seeking a solution to the controversy in a judicial proceeding. There are many medical staff appointment cases to this effect. ${ }^{62}$

By the same token, the hospital, whether public or private, must follow the provisions of its current by-laws. ${ }^{63}$ Thus, even if local law does not mandate that a private hospital grant due process to a physician who has been terminated as a staff member, he or she may obtain a court injunction requiring adherence to the procedural requirements set forth in the hospital's own by-laws. As noted earlier, minor, insignificant deviations from by-law provisions do not offend the physician's rights.

A final note is warranted before concluding. A physician-employee is in a different category from physicians appointed to the medical staff. The employed doctor is entitled to neither substantive nor procedural due process. Rather, his or her rights to continued employment depend upon the terms of the employment contract. Unless the contract provides otherwise, either expressly or by implication, the employee can be terminated, as a general rule, without a hearing, without prior notice and without a statement of the reasons for the termination. ${ }^{64}$ Similarly, nonrenewal of an exclusive service contract for radiology services does not require a hearing. ${ }^{6 s}$

\section{Concluston}

In conclusion, it must be emphasized that judicial review of medical staff privilege controversies is limited to determining whether the decision of the hospital's governing board was based upon reasonable, non-arbitrary criteria and accompanied by the requisites of procedural due process. When there is sufficient, credible evidence to support a decision that was reasonable in the circumstances, the court will not interfere and substitute its own judgment for that of the hospital's board. As stated by the Court of Appeals for the Fifth Circuit:

No court should substitute its evaluation of such matters for that of the Hospital Board. It is the Board, not the court, which is charged with the responsibility of providing a competent staff of doctors. The Board has chosen to rely on the advice of its Medical Staff, and the court cannot surrogate for the Staff in executing this responsibility. Human lives are at stake, and the governing board must be given discretion in its selection so that it can have confidence in the competence and moral commitment of its staff. The evaluation of professiona proficiency of doctors is best left to the specialized expertise of their peers, subject only to limited judicial surveillance. The court is charged with the narrow responsibility of assuring that the qualifications imposed by the Board are reasonably related to the operation of the hospital and fairly administered. In short, so long as staff selections are administered with fairness, geared by a rationale compatible with hospital responsibility, and unencumbered with irrelevant considerations, a court should not interfere. ${ }^{66}$

\section{References}

1. Joiner v Mitchell Councy Hosp. Auth., 125 Ga. App. 1, 2, 186 S.E.2d 307, 308 (1971), aff d 229 Ga. 140, 189 S.E.2d 412 (1972); Purcell v. Zimbelman, 18 Ariz. App. 75, 500 P.2d 335, 341 (1972); Gonzales v. Nork, No. 228566 (Sacramento Co. Super. Ct., Cal. 1973), rev'd on other grounds, 131 Cal. Rptr. 717 (1976); Corleto v. Shore Mem. Hosp., 138 N.J. Super. 302, 309, 350 A.2d 534, 537 (1975); compare Schenck v. Gov't. of Guam, 609 F.2d 387 (9th Cir. 1979) (District Court did not err in declining to apply emerging theory of independent or corporate hospital liability).

2. E.g., Gilstrap v. Osteopathic

Sanitorium, 224 Mo. App. 798, 810-12, 24 
S.W.2d 249, 256 (1929) (implied agency found as basis for employment of physician by sanitorium); c.f., Mulligan v. Wetchler, 39 App. Div.2d 102, 105, 332 N.Y.S.2d 68, 72 (1972) (hospital staff not bound to intervene in treatment of physician's private patient); Hoover v. Univ. of Chicago Hosp., 51 Ill. App.2d 263, 366 N.E.2d 925 (1977) (hospital not liable for assault by physician employee where tort was outside scope of employment).

3. When there is no employment relationship, there is no vicarious liability; a hospital is not liable for the negligence of an independent contractor physician. Cooper $v$. Curry, 92 N.M. 417, 589 P.2d 201 (1979).

4. See supra note 1. See also $\mathrm{MICH}$

Comp. Laws ANN. \$331.422 (1970); Mich

STAT. ANN. 814.1179 (12) (1969); IND. CODE

ANN. \$16-10-1-6.5 (Bums) (1973); ARIZ. REV.

STAT. ANN. \$36-445 (1972).

5. Shields, J.C., Guidelines for Reviewing Applications for Privileges, THE HospITAL MEdical StaFF 9(9): 11-17 (Sept. 1980)

6. For a concise statement of a public hospital's duty, see Moore v. Bd. of Trustees of Carson-Tahoe Hosp., 88 Nev. 207, 211-12, 495 P.2d 605, 608 (1972).

7. Hayman v. Galveston, 273 U.S. 414 416-17 (1927); Sosa v. Bd. of Managers of Val Verde Hosp., 437 F.2d 173, 176-77 (Sth Cir. 1971)

8. See Shelley v. Kraemer, 334 U.S. 1 (1948); Burton v. Wilmington Parking Auth., 365 U.S. 715 (1961)

9. E.g., Sosa v. Bd. of Managers of Val Verde Hosp., supra note 7 (notice of charge "reasonably related to operation of hospital" required for denial of admission to medical staff); Moore v. Bd. of Trustees of Carson-Tahoe Hosp., supra note 6 (hospital board may not act unreasonably or arbitrarily in denying restoration of medical staff privileges, even though conduct charged was not specifically prohibited by hospital by-laws).

10. Sams v. Ohio Valley Gen. Hosp. Ass'n, 413 F.2d 826 (4th Cir. 1969) (rule that staff physicians must locate their offices in the same county as hospital found unreasonable); Simkins v. Moses H. Cone $\mathrm{Mem}$. Hosp., 323 F.2d 959 (4th Cir. 1963), cert. denied, 376 U.S. 938 (1964) (allegations of racial discrimination in staff appointments); Silver v. Castle Mem. Hosp., 53 Haw. 475, 497 P.2d 564, cert. denied 409 U.S. 1048 (1972) (procedural due process found lacking where hospital failed to provide specific written charges prior to hearing for revocation of staff privileges).

11. Barrett v. United Hospitals, $376 \mathrm{~F}$. Supp. 791 (S.D.N.Y. 1974), aff d. mem., 506 F.2d 1395 (2d Cir. 1974). See also, Waters v. St. Francis Hosp., 618 F.2d 1106, 1107 (Sth Cir. 1980) (codification of common law right authorizing revocation of staff privileges does not convert revocation to state action): Hodge v. Paoli Mem. Hosp., 576 F.2d 563, 564 (3rd Cir. 1978) (mere receipt of HillBurton funds insufficient basis to support state action claim).

12. Barrett v. United Hospitals, supra note 11, at 797 .
13. Id at $800-05$.

14. Id. at 799 .

15. 42 C.F.R. $\$ 405.1021$ et seq. (1979).

16. Joint Commission on Accreditation of Hospitals, ACCREDITATION MANUAL FOR Hosprtals (Chicago, 1980) at 93-94; see generally, Darling v. Charleston Community Hosp., 33 Ill.2d 326, 211 N.E.2d 253 (1965), cert. denied, 383 U.S. 946 (1966) (JCAH standards are admissible in court and failure to adhere to them can constitute evidence of negligence).

17. See infra notes 20 and 21 and accompanying text.

18. See supra note 15 .

19. See supra note 16 .

20. Griesman v. Newcomb Hosp., 40 N.J. 389; 192 A.2d 817 (1963)

21. Woodard v. Porter Hosp., $125 \mathrm{Vt}$. 419, 217 A.2d 37 (1966); Hagan v. Osteo pathic Gen. Hosp., 102 R.I. 717, 232 A.2d 596 (1967); Khan v. Suburban Hosp., 45 Ohio St.2d. 39, 340 N.E.2d 398 (1976); Brickerv. Sceva Speare Mem. Hosp., 111 N.H. 276, 281 A.2d 589 (1971); Hawkins y. Kinsie, 540 P.2d 345 (Colo. App. 1975); McElhinney v. William Booth Mem. Hosp. 544 S.W. 2d 216 (Ky. 1977); Ascherman y. St Francis Mem. Hosp., 45 Cal. App.3d 507, 119 Cal. Rptr. 507 (1975); Storrs v. Lutheran Hospitals of America, 609 P.2d 24 (Alaska 1980).

22. Guerrero v. Copper Queen Hosp., 22 Ariz. App. 611,529 P.2d 1205 (1974), aff mem. 537 P.2d 1329 (1975) (private hospital); Williams v. Hosp. Auth. of Hall County, 119 Ga. App. 626, 168 S.E.2d 336 (1969) (public hospital)

23. 42 U.S.C. $\$ 291 \mathrm{et}$ seq, and $\$ 300 \mathrm{et}$ seq., 44 Fed. Reg. 29372 (1979).

24. Civil Rights Act OF 1964,42

U.S.C. A. $\$ 2000$ (c) (1966); 42 U.S.C.A. $\$ 1395$ et seq. (1973); see also e.g., Simkins $v$. Moses H. Cone Mem. Hosp., supra note 10 (participation in Hill-Burton program by private hospital sufficient basis for "state action" in denial of medical staff appointments and patient admissions on the basis of race); Foster v. Mobile County Hosp. Bd. 398 F.2d 227 (5th Cir. 1968) (state legislative creation and receipt of state and federal funds sufficient basis for finding "state action" in case involving alleged denjal of staff privileges on basis of race)

25. Parker v. Port Huron Hosp., 361 Mich. 1, 11-25, 105 N.W.2d 1, 6-13 (1960) (charitable immunity exception to general rule of tort liability, the bases for which are no longer compelling)

26. Parker v. Highland Park Hosp., 404 Mich. 183, 273 N.W.2d 413 (1978) (operation of hospital is not "state action;" fact that public hospital operates for the "common good of all" does not distinguish it from private hospital since modern hospital, public or private, operated essentially as a business).

27. Khan v. Suburban Hosp., supra note 21 (required applicants for appointment to document their training, experience, and specialty board certification or eligibility as a prerequisite for the granting of major surgical privileges); Rao v. Bd. of County
Commissioners, 80 Wash.2d 695, 497 P.2d 591 (1972) (required references).

28. Green v. City of St. Petersburg, 154 Fla. 3, 17 So.2d 517 (1944); Khan v. Suburban Hosp., supra note 21; Selden v. City of Sterling, 316 Ill. App. 455,45 N.E.2d 329 (1942) (mandated supervision for surgical privileges where surgeon's competence needed documentation or where a limited practitioner was granted privileges).

29. Fahey v. Holy Family Hosp., 32 Ill. App.3d 537, 336 N.E.2d 309 (1975) (required non-departmental physician to consult with qualified department member before performing any major surgery); $\mathrm{Mem}$. Hosp. $v$. Pratt, 72 Wyo, 120, 262 P.2d 682 (1953) and Peterson v. Tucson Mem. Hosp.. 559 P.2d 186 (Ariz. App. 1976) (required timely completion of medical records); Yeargin $v$. Hamilton Mem. Hosp., 229 Cal. 870, 195 S.E.2d 8 (1972) (required service in hospital's emergency room).

30. Yeargin v. Hamilion Mem. Hosp. supra note 29, Klinge v. Lutheran Hosp., 383 F.Supp. 287 (D.Mo. 1974), modified 523 F.2d 56 (8th Cir. 1975) (required adherence to reasonable medical staff by-laws, rules and regulations); Citta $v$. Delaware Valley Hosp., 313 F.Supp. 301 (E.D. Pa. 1970); Duby v. Baron, 369 Mass. 614, 314 N.E.2d 870 (1976) (sustained rule providing for summary suspension of staff member in circumstances indicating an immediate threat to safety of patients); Koelling v. Skiff Mem. Hosp., 259 Iowa 1185, 146 N.W. 2d 284

(1966); Laje v. Thomason Gen. Hosp., 564 F.2d 1159 (5th Cir. 1977) (documented clinical incompetence considered grounds for suspension or discipline).

31. Pollack v. Methodist Hosp., 392 F.Supp. 393 (E.D. La. 1975); Holmes v. Hoemaka Hosp., 573 P.2d 477 (Ariz. 1977); Revforth v. Fayelte Mem. Hosp., 383 N.E.2d 368 (Ind. App. 1978)

32. Davis y. Morristown Mem. Hosp. 106 N.J. Super. 33, 254 A. 2d 125 (1969) (periodic re-evaluation required).

33. Guerrero v. Burlington County Mem. Hosp., 70 N.J. 344, 360 A.2d 334 (1976).

34. Walsky v. Pascack Valley Hosp., 145 N.J. Super. 393, 367 A.2d 1204 (1976).

35. E.g., Blank v. Palo Alto-Stanford Hosp. Ctr., 234 Cal. App.2d 377, 44 Cal. Rptr. 572 (1965); Rush v. City of St. Petersburg, 205 So.2d 11 (Fla. App. 1968).

36. Adler v. Montefiore Hosp., 452 Pa. 60,311 A.2d 634 (1973) (cardiac catheterization); Dattilo v. Tucson Gen. Hosp., 533 P.2d 700, 23 Arix. App. 396 (1975) (nuclear medicine); Lewin v. St. Joseph Hosp., 82 Cal. App.3d 368, 146 Cal. Rptr. 892 (1978) (renal hemodialysis).

37. Griesman v. Newcomb Hosp., supra note 20; Foster v. Mobile County Hosp. Bd., 398 F.2d 227 (5th Cir. 1968); Ware v. Benedikt, 225 Ark. 185, 280 S.W.2d 234 (1955); Hamilton County Hosp. v. Andrews, 227 Ind. 217,84 N.E.2d 469 (1949).

continued on page 29 
Southwick References continued from page 9

38. Milford v. People's Community Hosp. Auth., 380 Mich. 49, 155 N.W.2d 835 (1968).

39. Sams v. Ohio Valley Gen. Hosp. Ass'n, supra note 10 (county lines per se do not relate to hospital's service area or to doctor's availability and ability to serve hospitalized patients adequately).

40. Ascherman v. St. Francis Mem. Hosp., 45 Cal. App.3d 507, 119 Cal. Rptr 507 (1975); Foster v. Mobile County Hosp. Bd., supra note 37.

41. Armstrong v. Fayette County Gen. Hosp., 553 S.W.2d 77 (Tenn. App. 1977).

42. Shaw v. Hosp. Auth. of Cobb County, 507 F.2d 625 (5th Cir. 1975) (podiatrist entitled to hearing); Davidson v. Youngstown Hosp. Ass'n, 19 Ohio App.2d 246, 250 N.E.2d 892 (1969) (private hospita) must act reasonably in passing on applications for staff membership); Touchton $v$.

River Dist. Community Hosp., 76 Mich App. 251, 256 N.W.2d 455 (1977) (cannot summarily dismiss application of podiatrist). Compare Aasum v. Good Samaritan Hosp., 395 F.Supp. 363 (D. Ore. 1975). But see Boos v. Donnell, 421 P.2d 644 (Okla. 1966) (chiropractors can be excluded from hospital staffs). Some state statutes prohibit hospitals from arbitrarily discriminating against persons practicing in certain allied health profession. E.g., CAL. HEALTH A SAFETY CODE $\$ 1316(1974)$ and $\$ 1316.5$ (1978) NEv. REv. StaT. $\$ 450.430$ and $\$ 450.005$ (1975).

Of course, requiring a due process hearing does not require the hospital to grant the podiatrist privileges. Shaw v. Hosp. Auth. of Cobb County, supra.

43. N.Y. PUb. Health Law \$2801-b (MCKINNEY) (1973) (podiatrists and others may not be denied staff privileges without stating reasons). In this connection see Fritz v. Huntington Hosp., 39 N.Y.2d 339, 348 N.E.2d 547 (1976); Fried v. Straussman, 393 N.Y.S. $2 d$ 334, 361 N.E. 2d 984 (1977).

44. See Reynolds v. St. John's Riverside Hosp., 382 N.Y.S.2d 618 (Sup. Ct. 1976) (physician's assistants must be considered by a hospital for privileges)

45. Theissen v. Watonga Mun. Hosp. Bd., 550 P.2d 938 (Okla. 1976); Peterson v. Tucson Gen. Hosp. 114 Ariz. 66, 559 P.2d 186 (Ariz. App. 1976); contra, Wyatt v. Tahoe Forest Hosp. Dist., 345 P.2d 93 (Cal. App. 1959).

46. Sosa v. Bd. of Man. of Val Verde Hosp., supra note 7 (physician abandoned obstetrical patients in active labor when they could not pay his fee; possessed an unstable physical demeanor and visible nervousness likely to jeopardize surgical patients; subject to fits of anger and rage: frequently moved the locus of his practice; had pled guilty to two felony charges in the past; had suffered suspension of medical license in Michigan and Texas (since restored in Texas); and failed to supply satisfactory current references).
47. Anderson v. Caro Community Hosp., 10 Mich. App. 348, 159 N.W.2d 347 (1968).

48. Huffaker v. Bailey, S40 P.2d 1398 (Ore. 1975) (by-law provision not unduly vague and reasonably related to quality of patient care); quoted in Ladenheim $v$. Union County Hosp., 76 Ill. App.3d 90, 394 N.E.2d 770 (1979)

49. See, e.g., Miller v. Eisenhower Med. Center, 166 Cal. Rptr. 826, 614 P.2d 258 (1980); see also Staube v. Emanuel Lutheran Charity Bd., 287 Ore. 375, 600 P.2d 381 (1979); Robbins v. Ong, 452 F.Supp. 116 (S.D. Ga. 1978)

50. Rosner v. Eden Township Hosp. Dist., 58 Cal.2d 592, 375 P.2d 431, 25 Cal. Rptr. 551 (1962).

51. Joint Commission on Accreditation, acCREditation ManUal for Hospitals, supra note 16 , at $95,103-05$.

52. Silver v. Castle Mem. Hosp., supra note $10,53 \mathrm{Haw}$. at $48485 ; 497$ P.2d at 571 72.

53. Garrow v. Elizabeth Gen Hosp. 155 N.J. Super. 78, 92, 382 A.2d 393, 400 (1977).

54. Klinge v. Lutheran Charities of St. Louis, 523 F.2d, 56, 63 (8th Cir. 1975); Hor tonville Joint Sch. Dist. No. I v. Hortonville Educ. Ass'n, 426 U.S. 482, 493 (1976).

55. Woodbury v. McKinnon, 447 F.2d

839, 844 (Sth Cir. 1979); Ascherman v. San Francisco Med. Soc, 39 Cal. App.3d 623 648, 114 Cal. Rptr. 681, 697 (1974).

56. Silver v. Castle Mem. Hosp., supro note 10, 497 P.2d at 571; Ascherman v. San

Francisco Med. Soc, supra note 55, 114 Cal. Rptr. at 697

57. Anton v. San Antonio Community Hosp., 140 Cal. Rptr. 442, 458, 567 P.2d 1162 1178 (1977)

58. Garrow v. Elizabeth Gen. Hosp. \& Disp., 79 N.J. 549, 566-67, 401 A.2d 533,

541-42 (1979).

59. Brickman v. Bd. of Dir. of W. Jefferson Gen. Hosp., 372 So.2d 701, 705 (La. App. 1979).

60. Joint Commission on Accreditation, ACCREditation Manual for Hospitals, supra note 16 , at 104

61. Johnson, R.L., How Much Process Is Due? Trustee 32(10): 12 (October 1979).

62. E.g., Garrow v. Elizabeth Gen. Hosp., \& Disp., supra note 58, 401 A.2d at 538; Brickman v. Bd, of Dir. of W. Jefferson Gen. Hosp., supra note 59; Shulman v. Wash. Hosp. Center, 348 F.2d 70 (D.C. Cir 1965).

63. Margolin v. Morton F. Plant Hosp. Ass'n, 348 So.2d 57 (Fla. App. 1977). 64. Burkette v. Lutheran Gen. Hosp. 595 F.2d 255 (5th Cir. 1979).

65. Kushner v. Southern Adventist Health and Hosp. Syst., 260 S.E.2d 381 (Ga. App. 1979).

66. Sosa v. Bd. of Man. of Val Verde Hosp., supra note 7, quoted in Laje v.

Thomason Gen. Hosp., supra note 30, at 1163.
Reference Shelf continued

Smoking and the Law

Blackburn JD, Legal Aspects of Smoking in the Workplace, LABOR LAW JOURNAL 31(9): 564-69 (Summer 1980).

Sapolsky HM, The Political Obstacles to the Control of Cigarette Smoking in the United States, JourNal of Health Politics, Policy AND LAW 5(2): 277-90 (Summer 1980) [8-1378].

\section{Women's Health}

Pratt JH, The Unnecessary Hysterectomy, SOUTHERN MEDICAL JOURNAL 73(10): 1360-64 (October 1980) [9-116].

\section{Workers' Compensation}

Edes NB, Compensation for Occupational Diseases, LABOR LAW JOURNAL 31(10): 595-601 (October 1980).

Feldman RS, Workers' Compensation: The Development of the Stress Injury Concept, TRIAL 16(9): 40-41, 60-61 (September 1980) [9-210].

Miller CN, Workers' Compensation: Preparing the Occupational Disease Claim, Trial 16(9): 26-30,60 (September 1980) [9-209].

Smith DR, State Workers" Compensation Law: A Look into the 1980s, TRIAL 16(9): 42-45, 62-63 (September 1980) [9-211].

Tinsley LC, Workers' Compensation Laws: Key Amendments of 1979 MONTHLY LABOR REVIEW, pp. 19-25 (February 1980) [9.013].

\section{Back issues of Modicologal Nows}

Microfilm or microfiche copies of back issues of MEDICOLEGAL NEWS are available from University Microfilms International, 300 North Zeeb Road, Ann Arbor, MI 48106.

A bound volume of MEDICOLEGAL News, volumes one through five, is available from William $S$. Hein \& Co., Inc., 1285 Main Street, Buffalo, NY 14209.

Individual back issues of MEDICOLEGAL NEWS, including the most recent volume, are available from the American Society of Law \& Medicine, 520 Commonwealth Ave., Boston, MA 02215. 